\title{
Research on the Development of Microteaching and the Applications on Contemporary College English Teaching
}

\author{
Yinna Su \\ Hebei Institute Of Communications, \\ Shijiazhuang,Hebei,050071 China
}

\author{
Yahui Hu \\ Hebei Institute Of Communications, \\ Shijiazhuang,Hebei,050071 China
}

\begin{abstract}
In this paper, we conduct research on development of microteaching and the applications on the contemporary college English teaching. Along with the rapid development of higher vocational education, the ministry of education put forward to improve the quality of higher vocational education teaching, it brought opportunities to the development of higher vocational English, also poses a challenge. Based on traditional higher vocational English teaching experience, from student-centered teaching methods, make full use of modern computer technology to multimedia teaching, reasonable practical teaching, training teachers, reform of the examination system and this paper expounds the understanding of higher vocational English teaching reform, and related suggestions are put forward. Through combining the microteaching approach, we optimize the traditional teaching paradigm and the performance which is meaningful and necessary.
\end{abstract}

Keywords- Microteaching, College English, Teaching, Contemporary, Development Pattern.

\section{Introduction}

College English is many college professional must learn course, visible for us to cultivate the college students of the new century college English how important it is. With the advancement of education industry reform, various aspects of the level of colleges and universities in China have increased, the college English teaching has made great progress, but we also want to see, also is the education of the colleges and universities of our country, there are many problems. Only we correctly understand the situation clearly, and the status quo, starting from national conditions of our country, using scientific and reasonable teaching methods, to continue to solve the new problems facing the good we are now, can we fundamentally solve the problem to achieve the purpose of better training of English talents.

The basic teaching methodologies for the current English education could be generally separated into the listed parts. (1) The time distribution of core cooperation. The allocation of learning time after class to improve my English level is very important, according to oneself circumstance in learning, for sure in the listening, speaking, reading, writing, such as learning program on reasonable allocation of time, in the different stages of the learning, according to the students' learning and teaching schedule, recommend some reference books for students to choose from. (2) A variety of specific skills. We can through class teaching, extracurricular time or seminar teach student learning, and thus improve their learning level. (3) To improve students' ability of the remember rate. By telling the students about the basic knowledge of memory, let them understand the forgetting curve changes, thus understood the importance of the "repeatedly" in the memory. (4) The use of reference books. During the period of study, students will meet all kinds of problems, often will be addressed by others, therefore, reference books at the moment there is a place, how to use reference books is the key of the students learning, the teacher let the students fully understand the use of reference books, how to make use of reference books to get best help on 
learning. (5) Read and recite. The role of reading aloud is a lot of, such as the correct pronunciation, and enhances the language sense to raise level of comprehension and memory more vocabulary that will be meaningful [1-2].

Microteaching is a kind of new method of training teachers and in-service teachers' teaching skills, and it is with the development of science and technology, audio and video equipment and information technology is widely used in teaching. Microteaching has the real scene simulation teaching, teaching skill decomposition, the teaching goal clear, teachers provide professional guidance and the teaching feedback directly, evaluation objective as can practice and class size, the advantages of the class time is short, less is known as the sixties and the seventies of the 20th century's most influential one of the normal education innovation. In the figure one, we show the detail steps and components [3].

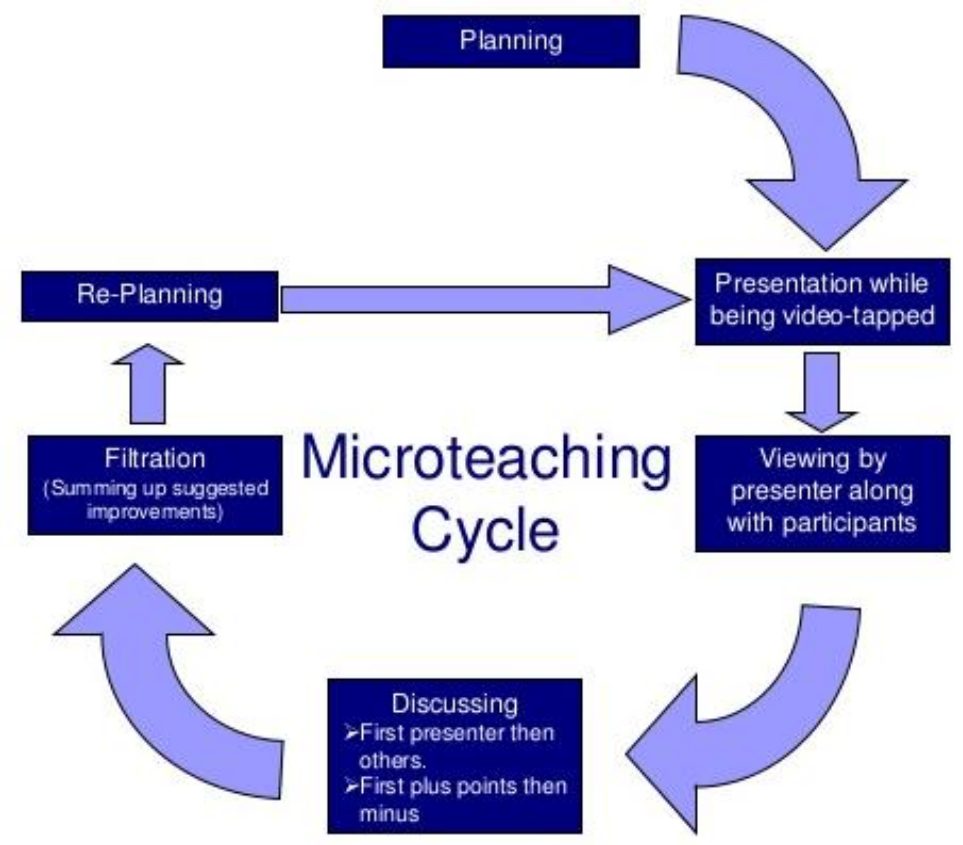

Figure 1. The General Components of the Microteaching Methodology

In this paper, we conduct research on the development of microteaching and the applications on the contemporary college English teaching. Only attach the importance to college English teaching, can really improve students' listening comprehension ability, speaking ability, reading comprehension, writing ability and the translation ability, to maximum expand vocabulary. College English education should be based on social needs and teaching practice, according to the characteristics of the students in colleges and universities, research and innovation of teaching concept, teaching mode and teaching content, give full consideration to the habit of students to obtain the information knowledge, train the ability of basic language, culture, and professional spirit, really create a new college English teaching atmosphere to enhance the confidence of the students and teachers and strength.

\section{The Proposed Methodology}

The English Teaching Reform Orientation. The goal of higher vocational English teaching in our country is to cultivate students to master some basic knowledge of English and basic skills, focused on the professional and technical needs, 
strengthen the professional knowledge and skills, to improve students' ability of applying English in the practical work. But there are a lot of English teaching in higher vocational college infrastructure is relatively backward, can't satisfy the demand of the new educational philosophy which affects improvement of English teaching quality and teaching level.

The traditional English teaching, the student basically is "writing", mainly takes an exam the talent cultivation, in terms of listening and speaking, lack the necessary training, this leads to the students after graduation as can't do use their professional knowledge the global trend of integration of further deepening, the requirement of English reading and speaking skills. For this kind of situation, the new requirements of higher vocational colleges must consider the unit of choose and employ persons, and to reform their teaching patterns and reshape the image of the higher vocational students of English.

Based on the mentioned perspectives, we should take the following suggestions into consideration. (1) Deepening the reform of English teaching content. Construction to cultivate professional ability and improving students' basic quality as the goal of English curriculum structure, reform of English class teaching content, make it really meet the requirements of vocational education as is the key and difficult point for English teaching reform that also is the core of the English teaching reform. (2) To strengthen the construction of teaching staff. In the teaching practice, adhere to the combination of dominant and main body. Teaching quality involves many factors, but the student is the main body of the teaching activities as teachers should play a leading role in the teaching activities, to combine the dominant and main body. (3) The reform of English teaching mode and teaching method. The training objectives of English teaching must be based on different updating the teaching contents and teaching methods. Higher vocational English teaching should give priority to with the practical communicative ability training. (4) To do a good job of teaching material selection and construction. On the teaching material design, can be a huge increase in students after graduation will be in contact with operating instructions, such as product introduction, and the maintenance guide material, supplemented by the corresponding class activities with the arrangement [4-5].

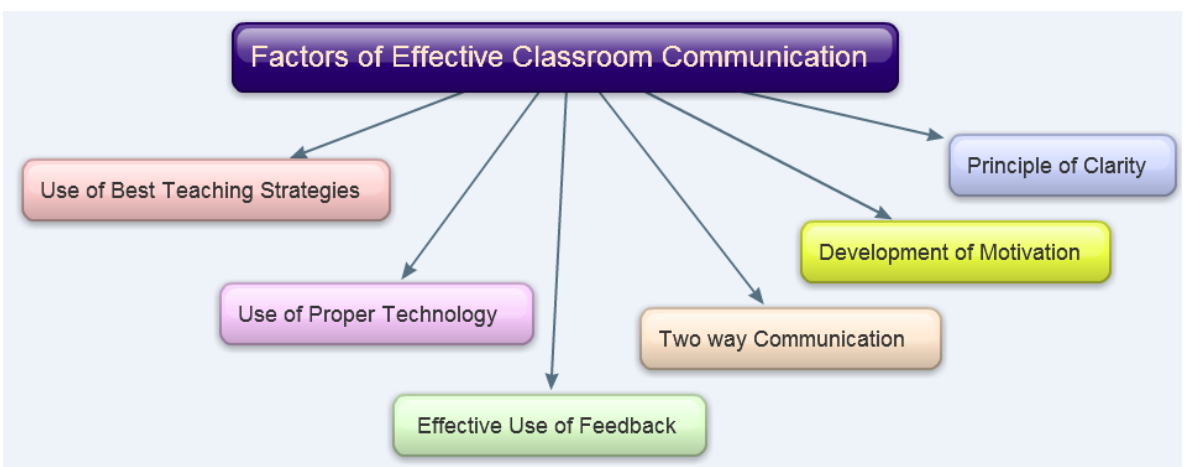

Figure 2. The Illustration of the Effective Classroom Communication

The Principles of the Microteaching. In the context of the lack of the English teaching under the background, the traditional English teaching relying too much on the teacher's explanation and basic demonstration, or recording of the auxiliary equipment, the teacher speaks, students practice less, learning efficiency is low and the effect is not obvious. Therefore, the combination of the micro based teaching is necessary and it can be finalized from the listed aspects.

- The micro-standard teaching of basic English listening. Pure microteaching 
system will be the traditional foreign language listening course combined class into visual, listening, speaking, use various teaching media, and make the sound image harmony, make the combination of language information with specific situations that is no longer a mechanical repetition of the listening as also do not need old question and answer, but in the audio-visual affectionately said multidimensional teaching mode, stimulate students' learning interest, make them in real language environment, to do meaningful listening exercises, through constant practice, in the practice also with ease, very skilled to understand with effective communication.

- The micro-standard teaching English writing. We can choose a snippet to let the student get practice dubbing grouping and then recording paper, again with the original. Modifies not real English words. Through the micro-standard teaching that can become the boring writing class vivid rise, in this way, the students to master and memory beautiful sentences is also stronger.

- English reading course of the microteaching. If before reading, the teacher to collect a large amount of material, use in the form of audio, video, or basic performance and microteaching, important present students with the background of the article, widen their thinking, also paved the way for the primary reading [6].

As the applicable suggestions and the advices, the executive steps of the micro-standard teaching can be de-composed into the listed aspects. (1) Set the teaching goals. English as a language itself is extremely complex, involving a variety of choice of the multidimensional system. Teachers before practice class, carefully study the teaching material, summarized the key and difficult point for each chapter, and systematic, the scientific classification, setting and the corresponding teaching goal. (2) Teaching well-prepared. As an organizer of teaching, teachers must be aware of activity, the purpose of the situation of students, possible problems and solutions are available. Preparation significance lies in through teacher give enough guidance and help in advance, so that the students can successfully complete the required learning activities. (3) The practice teaching. In terms of the practice teaching, the classroom is the student to the language knowledge they learned in class practice, practical skills and preparation for inspection for a period of time, to the student, therefore, this link is the key in the process of the real-world practice courses.

The Feed-back Learning Pattern. Near development area theory adhere to carry out interactive learning between companion for learners to share knowledge, sharing between learning experience, so as to effectively improve the learners' learning efficiency, stronger for the students to master study skills and strategies to provide the possibility of more. The adjacent development area theory thinks the company common learning mode as can cultivate the ability to stimulate the learners' autonomous learning, is beneficial to them in future in the process of learning, alone to discover problems to solve the problem. In the process of interactive feedback in higher vocational English teaching, teachers should pay attention to create the good teaching situation, mainly by way of asking questions. In the process characteristic of higher vocational English account, combined with the students' basic ability level, using English, thinking ability, communication ability, such as the actual situation, stimulates the student to participate in the enthusiasm of learning, through the communication between students and students, teachers and students to improve students' ability of practical application of English.

Feedback is very important in writing teaching, most of the authors or we want to be able to get 
someone else to read his works after the feedback, so we can know what deficiencies still exist in the writing, in the later writing where main attention should be paid. Any article can't be done perfectly, will surely there are some deficiencies, amendments is the way to these deficiencies perfect [7-8].

The Revised English Education Pattern. Under the guidance of new basic education concept, strengthen the teaching process of class situation set up to promote the efficiency of teaching and the students' initiative is of great significance. In the setting of teaching situation, also pay attention to the situation in the process of life, try to use common scenario for their situation in life settings, facilitate students' understanding of life situation, so that they can from life situations to the class situation to deepen the understanding of college English knowledge, improve the ability to solve the problem of the college English. For the common English conversation practice, for example, we can set the scene accordingly in the process of teaching and let the students to perform some specific content, in the process of performing to deepen the understanding of some knowledge of English. Specifically, we should follow the listed guidelines. (1) Practical principles. Task should be closely connected with the real world and the theme of the student's study should be more targeted and practical. (2) Autonomy principle. Provide students choose according to the own interest and display form of decision-making opportunity, students learn to liberty, freedom, so as to effectively promote the development of the students' creative ability. (3) The principle of openness. The task project should have the diversity and selectivity. In general, the task-based teaching evaluation should pay attention to the student ability development process in the project activities, the evaluation content should include the students to participate in the activities of each link performance and the quality of the work. (4) Comprehensive principle.
Task has a discipline and students to the characteristics of the integrated use of skills.

\section{Conclusion}

In this paper, we conduct research on the development of microteaching and the applications on the contemporary college English teaching. English is a practical course, all kinds of English language skills must be acquired through practice of individual students. Learning effect depends largely on the students' subjective initiative. So when it uses the hierarchical teaching, differential treatment in the education, to maximize and arouse the initiative of teachers and students, teach and learn a foreign language well. Only the schools, teachers and students work together to the college English teaching reform will succeed, to cultivate more talents foreign language level is higher. In the future, we will combine more teaching methodologies to enhance the general performance of the current research.

\section{References}

[1] Dingfang, Shu. "The SFLEP National College English Teaching Contest and teacher development [J]." Foreign Language World 3 (2012): 007.

[2] Bao, Wenshu. "Research on college English teaching based on intercultural communication in engineering universities." World Transactions on Engineering and Technology Education 12.3 (2014): 191-195.

[3] Yuan, Chen. "Application of Internet of Things in Listening and Speaking Teaching for English Majors [J]." China Educational Technology \& Equipment 6 (2013): 055.

[4] Lan, Wang. "A study on learners' emotional experience under level-based college English teaching model $[\mathrm{J}]$." Journal of Jiamusi Education Institute 8 (2013): 118. 
[5] Hai-yan, Z. H. O. U. "Probe into the Reform of Web Theme-based Approach to College English Teaching." Higher Education Forum. Vol. 11. 2011.

[6] Gao, Xuesong Andy, Yanyi Liao, and Yuxia Li. "Empirical studies on foreign language learning and teaching in China (2008-2011): A review of selected research." Language Teaching 47.01 (2014): 56-79.
[7] CHEN, Hai-yan, et al. "Constructing a new English teaching mode for nursing students in Sino-foreign joint program [J]." Chinese Journal of Nursing Education 8 (2013): 012.

[8] Pishghadam, Reza. "Life syllabus: A new research agenda in English language teaching." Perspectives 19 (2012). 